\title{
IMPACT OF RIVERBANK EROSION HAZARD IN THE JAMUNA FLOODPLAIN AREAS IN BANGLADESH
}

\author{
M R Rahman ${ }^{1}$
}

\begin{abstract}
The paper provides an overview of Bangladesh populations displaced by river erosion. The study describes the physical environmental conditions of the study area with a special attention to natural disasters of the region. It focuses the socio-demographic profile of the victims of the study area. Caused riverbank erosion a considerable proportion of the victims are compelled to leave the original homestead plot and take shelter by the road side embankment, neighbors land and relative land. The health condition of the victims is very low. Since the natural environmental situations, the economic crisis and poverty have been found to be related to natural disaster like riverbank erosion, so in this decade of environment the policy makers and researcher at the national level need to be aware of the magnitude of the environmental conditions of the riverbank erosion victims. In fact that, caused riverbank erosion every year unemployment, landless and poverty are increasing which is responsible to country wide unstable condition.
\end{abstract}

Keywords: Riverbank, Impact, Hazard, Jamuna, Bangladesh

\section{INTRODUCTION}

About all the studies on riverbank erosion victims in Bangladesh have been done by the geographers from geographic point of view. These studies mostly used data obtained by the Riverbank Erosion Impact Study (REIS). Rahman (1986) conducted a short field survey in Bhuapur Thana to Tangail and Hizla Thana of Barisal in ordar to identify the possible economic strategies of the victims for their survival. Rogge (1991) revealed that the victims in Bangladesh have been suffering from the sheer lack of institutional response in formulating and undertaking adjustment strategies. Elahi 1991 used data from secondary resource development approach in dealing with the settlement strategy for the victims in Bangladesh. Alam 1990 identified socio-economic and political dynamics of charland (island) settlement using secondary data.

Excepting a very few studies (viz., Haque 1988, Zaman 1988, Elahi et al. 1990, Islam and Islam 1985, Rogee 1991) most of the research on riverbank erosion impact dealt with geomorphic phenomena in a very particularistic manner. For that reason, this research will have an emphasis on an integrated an approach focusing on socio-economic and environmental perspectives. It is known to us that the deltaic plain of Bangladesh comprises the major rivers of the Jamuna. From this point of view, this research covers the major riverbank erosion affected areas of the country like the Jamuna riverbank which are, on a regular basis, susceptible and vulnerable to riverbank erosion. In this context, this research will be very much helpful for the academicians, national planners, development workers, and the policy implementers of Bangladesh.

${ }^{1}$ Institute of Environmental Science, University of Rajshahi, Rajshahi-6205 


\section{MATERIALS AND METHODS}

Effected peoples are stands by the side of Jamuna River. A vast of amount of land of this village already in Jamuna River. Some peoples have been lost residence some have been lost cultivated land, some have been lost others and it is being continued.

Through administering the structured questionnaire schedule the household census data have been obtained. These data reveal that one village has 263 households with a population of 1050 . Out of them 164 households with a population of 580 are riverbank erosion victims. Another village contains 170 households and its total number of population is 720 . Out of them 87 households with a population of 302 are riverbank erosion victims.

Primary and secondary data are being used in the present study. The principal tools for collecting the primary data are questionnaires and interviewing two techniques of the survey method. The major sources of data used in this study are collections and analysis of local level office report, evaluation of government and semi-government projects, programs and census reports, published reports and articles etc. The present study includes some case histories and case studies of the victims and notable issues to constitute another part of data collection.

\section{RESULT AND DISCUSSION}

Bangladesh is the largest delta in the world, formed by the Ganges, the Brahmaputra, and the Meghna (GBM) river system. This delta is characterized by flat terrain interlaced with an intricate system of about 700 rivers, canals, and streams, with a total length of approximately 22,155 km (BBS 1979, 1984), which carry an enormous quantity of sediment-laden water downstream. Over 92 percent of the annual runoff generated in the GBM area flows through Bangladesh, which is only about 7 percent of the total catchment's area (Ahmad, 2000). Thus, a vast amount of water flows through Bangladesh. It is estimated that every year an average of 870 Million Acre Feet (MAF) of water flows into the country from India. The amount of rainfall received within the country is estimated at 203MAF, with evaporation, evapotranspiration, and deep percolation losses probably accounting for about 120MAF. This means that about 953MAF flows out to sea-from that 914MAF flows through the GangesBrahmaputra delta (within Bangladesh), and 39 MAF through the rivers of the Chittagong sub-region and Feni district (Rashid 1991).

During the peak flow season (July-September) most of the rivers normally overflow their banks onto the low-lying surrounding flat land, which is essential for providing vital moisture and fertility to the soil. However, occasionally abnormal conditions lead to drainage congestion, excessive rainfall runoff, and storm-tidal surges that induce high-magnitude flooding that inundates large areas, and causes widespread damage to crops and property. The devastating floods of the recent past are due to excessive rainfall in the GBM catchment area, and synchronization of peak flow of the Ganges and the Brahmaputra-Jamuna rivers. The likelihood of abnormal floods is also increased due to infrastructure development activities that neglect proper concern about environmental impacts and drainage facilities. An analysis of hydrographs and other hydrological data of a few selected stations indicated the following salient features (Haque and Zaman 1993).

The synchronization of backflows of the major rivers accounts for the floods in the years 1954 (30 days), 1974 (27 days), 1987 (30 days), and 1988 (30 days). The synchronization accentuated the disastrous and catastrophic flood of 1988. 
The mean annual rainfall in Bangladesh varies from about $1400 \mathrm{~mm}$ in the western part of the country, to almost $5000 \mathrm{~mm}$ in the northeast region. There are wide seasonal fluctuations, with about 90 percent of the rainfall occurring during the four months of the monsoon period (June-September). A number of constraints are inherent in this monsoon-dependent rainfall and climatic pattern, which can lead to excessive amounts of rainfall and floods, or inadequate rain resulting in drought. Along with the floodwater, the rivers of Bangladesh carry huge amounts of sediments, an estimated 2.4 billion m.tons/year. The sediments are washed down from highlands on three sides of the Basin, particularly from the Himalayas, where the slopes are steeper and the rocks are less consolidated. Erosion plays an important role in the siltation process, and the water-holding capacity of rivers. The deterioration of the river system due to siltation is one of the causes of floods in Bangladesh. The river sediments are subjected to coastal dynamic processes generated mainly by river flow, tide, and wind actions. The ultimate result may be additional new land in some places due to accretion, and loss of land in some other places due to erosion. As a result of sedimentation, the formation of chars (islands) through accretion takes place. These undesirable chars in the river system threaten inland water navigation, cause erosion in the riverbanks, and create other socio-economic problems for people due to land loss and displacement. Erosion in the coastal regions of Bangladesh is caused by a number of factors, such as high monsoon wind, waves, and currents, strong tidal actions, and storm surges (Ali 2000).

\section{Global Environmental Pressures}

The 57 main rivers flowing through Bangladesh are trans-boundary; 54 of them have origins in India, and 3 in Myanmar. The upstream deforestation, heavy rainfall, melting of glaciers, and soil erosion play a vital role in causing siltation in riverbeds. This in turn leads to natural disasters like floods, flash floods, etc. The upstream activities also enhance the magnitude of damages caused by these disasters. The upstream withdrawal of water due to the Farakka barrage across the Ganges in India leads to local drought conditions in regions of Bangladesh. There is firm scientific evidence that largely due to human activities the concentration of greenhouse gases in the earth's atmosphere is increasing. Higher precipitation may increase the area and depth of flooding, which will require additional measures for protection and adaptation. Other probable pressures include disruption of the monsoon rhythm, prolonged drought, and increased frequency of cyclones. Bangladesh is one of those poor countries which may face the irony of adapting to and mitigating the consequences of man-made global warming and climate change, which are largely not of their own making; while they have little human, societal, technological, or financial capability for such adaptation and mitigation (Huq et al. 1999). Bangladesh is thought to be one of the most vulnerable countries in the world to Climate Change and Sea Level Rise (SLR). The apprehended Climate Change and SLR will lead to coastal inundation throughout the world, particularly along low-lying coastal areas. In Bangladesh, it is likely to inundate wetlands and lowlands, accelerate coastal erosion, increase the risk of flood and cyclone disasters, change rainfall pattern, create drainage and irrigation problems; and increase salt water intrusion into ground water, rivers, agricultural, and coastal forestlands. This may in turn cause damage to port facilities and coastal embankments/structures, destroy quality farm lands, disrupt mangroves, fisheries and bird habitats, result in loss of recreational beaches, and affect cyclone and storm surge protection measures in the coastal areas (Ali, 2000).

The SLR might make an impact on the country as a whole by inundating one-tenth of the total land area along the coastal belt. If this happens, about ten million people living in the coastal areas of Bangladesh will be forced to migrate further inland. This will put a tremendous population pressure on the mainland. 


\section{Flood}

Extensive studies by various authors have shown that the area of flooding at different times, varied from 31 per cent to 85 per cent of the total area of the country (Choudhury and Hossain 1981, Matin and Hussain, 1988, Pramanik, 1988 and Rashid and Pramanik, 1990). During the 1988 flood, 8 out of 10 stations in the Brahmaputra basin exceeded the flood level of 1987, and for the Ganges basin that occurred in 5 out of 9 stations. The flood level of the Ganges upstream of Hardinge Bridge was higher in 1987, than in the 1988 flood. Flood-flow of the Ganges was also higher in the 1987 flood. In addition, in the southeastern hill basin, the flood level of all the streams was higher in 1987, than in 1988. During 1987 an area of 57,270 sq. km was inundated, whereas in 1988 an area of 81,831 sq. km was inundated. Bangladesh is a land of many rivers, and heavy monsoon rains. Therefore, the country is subject to inundation by overflow from the riverbanks due to drainage congestion, rainfall run-off, and storm-tidal surges. Some 30 to 35 percent of the total land surface is flooded every year during the wet monsoon (Milliman et. al., 1989). These normal floods are considered a blessing for Bangladesh-providing vital moisture and fertility to the soil through the alluvial silt deposition. Only abnormal floods are considered disastrous, i.e., the high-magnitude events that inundate large areas, and cause widespread damage to crops and properties. During the peak flow season (July, August and September), most of the rivers overflow their banks, and deposit silt on the flood plains - providing vital moisture and fertility to the soil.

Thus, the normal floods are considered a blessing for Bangladesh. Only abnormal floods are considered disastrous, i.e., the high-magnitude events that inundate large areas, and cause widespread damage to crops and properties.

Flood is more or less a recurring phenomenon in Bangladesh, and often within tolerable limits. Occasionally, it becomes devastating. In 1997, 1988, 1998, and 2000, Bangladesh faced unprecedented floods, causing massive loss of life and property.

Excessive rainfall in the catchment area. Synchronization of the peak water levels of all the major rivers of Bangladesh. Sometimes solar eclipse retards the outflow of water drainage by raising the tidal level.

\section{River Erosion Social Impacts and to the Old Embankment Village on the Jamuna River}

In 2003 a community of squatters on what was called the old embankment resided on Bangladesh Water Board (BWDB) owned land without hope of an alternative to having its mostly kutcha structures swept away by the Jamuna River during succeeding Monsoon seasons. The old embankment had been some distance inland at one point, but the Jamuna waters had eroded all lands standing between its waters and the largely earthen embankment. Many of these squatters had once owned land that now lay under the river and so were now landless and without anywhere else to settle in one of the most over-crowded countries in the world. The dry channel migration over the decade 1992-2002 in relation to the present old embankment community, which may be referred to as the .Old Embankment Village in this paper. The old embankment village plight was far from unique, as it was one of communities along the Jamuna and the other major Bangladesh rivers in a similar situation.

Riverbank erosion is a perennial problem in Bangladesh. Large monsoon flow transporting extreme amounts of sediment from the Himalayan Mountains to the sea flow through the delta of Bangladesh formed by the same soils. These fine soils have no resistance to the flowing water and are easily transported and deposited. As a consequence the large rivers have quite an unpredictable behavior with the permanent risk of riverbank erosion. Riverbank erosion can exceed one kilometer per year and poses a substantial risk to floodplain dwellers. The loss of land is accompanied by a loss of 
infrastructure such as flood embankments, schools, hospitals, cultural and religious monuments and, of course, agricultural lands and assets.

It has been estimated that tens of thousands of people are displaced annually by river erosion in Bangladesh, possibly up to 100,000 . The first immediate relief after erosion is provided by the nearby flood embankments. As a consequence of continuous erosion many embankments are densely occupied by squatters (Faruque 2007).

While no recent figures are available, historic studies from the mid 1980s indicate that in some slums in Dhaka more than $40 \%$ of the population named river erosion as primary cause for their migration into slums. The life on the flood embankments and in slums results in special hardship, such as a lack of minimum services, drinking water, ration cards, schooling for children, health facilities, and attention of the local government. In 2007 nearly 14 Million people (10\% of the population) in more than 20 districts were affected by the floods limited to the Brahmaputra River. The flood damages are counted by the billions. Considering the extreme population density of more than 1000 persons per square kilometer. (Viswanathan and Ravi 2007).

Most households earned their income through daily wages in surrounding, more stable communities. A very few ran small businesses; for instance the village had six shops selling tea and sundries. Very few people living on the bankline depended directly on farming as a source of income, as virtually all villagers had been rendered landless by river erosion. Over seventy percent of households had an income below the official poverty line in Bangladesh and over fifty percent were living below the extreme poverty line, with on average households earning less than a US\$ dollar per day.

Resettlement Plan and were enumerated in the socio-economic survey covering both communities and from which socioeconomic data is quoted here. In fact, the OE Village proper was some 110 households, and the two communities in this paper are in instances treated, for illustration purposes, as one. Another, very similar, village on the bank of the Mahananda River also in Bangladesh is described in Viswanathan and Ravi 2007. The official poverty line was calculated at 2,122 KCal intake per person per day ensured by a per capita monthly income of about taka 700, approximately US\$10.

Without any intervention it is clear that the Old Embankment would have over a short period of years eroded into the Jamuna River and the village people would have once again been forced to relocate, possibly to one of Bangladesh cities. As with flood control measures elsewhere in Bangladesh the reliance along this stretch of the Jamuna was on earthen embankments, polders, and drainage. Overall in Bangladesh, there are a total of 5,695 km of such embankments, including 3,433 km in the coastal areas, 1,695 flood control/regulating structures, and 4,310 km of drainage canals that have been constructed by the Bangladesh Water Development Board (BWDB).

Unfortunately these earthen embankments can easily breach and can be damaged by riverbank erosion, and most of the embankments in Bangladesh have experienced breaching and erosion more than once since their completion (Viswanathan and Ravi 2007).

The PIRDP was begun in 1972 and ran through 1992 to improve the basic infrastructure of one of the most important and vulnerable agricultural areas in the heart of the country. It was designed to increase agricultural production, generate employment and improve farmers' living conditions by providing flood embankments, improving existing channels and installing drainage pumps to protect 
an area of about 185,000 ha from annual flooding. The overall cost had been about US\$85 million, and the Project directly benefited more than 167,000 rural households.

Squatters are commonly people displaced by river erosion along the banks or, in certain cases, from river islands (called chars). The old embankment squatters had lost all their land and were only able to keep a minimum of property in the form of a temporary house consisting mainly of bamboo and corrugated sheets, some furniture and a few life-stock.

On settling on the Old Embankment Government land, the villagers had cut platforms into the existing embankments, further weakening them, to build their houses on an elevation less prone to flooding. As this Government land was required for construction, following Bangladeshi law, the squatters were illegal settlers. On the other hand, as per the ADB.s Policy on Involuntary Resettlement, these often hard-core poor were accorded special rights and grants to reduce their poverty during and beyond the resettlement process itself. The Project offered to resettle these. Affected people through self relocation or through providing cluster relocation. As a sizable community, the Old Embankment Village chose to be relocated to a Resettlement Village to be developed by the BWDB, as did another close by community in what the Project termed the .Wave Eroded Area. In contrast, most of the river bank protection civil works for PIRDP and MDIP were carried out on sparsely or non-populated river banks where the few Affected Persons chose to self relocate from the Project right of way.

\section{Riverbank Erosion}

Riverbank Erosion an endemic and recurrent natural hazard in Bangladesh. When rivers enter the mature stage (as in the case with the three mighty rivers, Ganges, Brahmaputra and Meghna) they become sluggish and meander or braid. These oscillations cause massive riverbank erosion. Every year, millions of people are affected by erosion that destroys standing crops, farmland and homestead land. It is estimated that about $5 \%$ of the total floodplain of Bangladesh is directly affected by erosion. Some researchers have reported that bank erosion is taking place in about 94 out of 489 upazilas of the country. A few other researchers have identified 56 upazilas with incidence of erosion. At present, bank erosion and flood hazards in nearly 100 upazilas have become almost a regular feature. Of these, 35 are severely affected. For example, a newspaper report stated that over 25,000 families were rendered homeless in June 1993 by riverbank erosion in 16 districts. Some rivers cause erosion in large scale and high frequency due to their unstable character. These rivers assume a braided pattern consisting of several channels separated by small islands in their courses. During the last 200 years or so, the channels have been swinging between the main valley walls. During the monsoon, extensive over bank spills, bank erosion and bank line shifts are typical. The gradual migration or shifting of channels of the major rivers in Bangladesh amount to anywhere between $60 \mathrm{~m}$ to $1,600 \mathrm{~m}$ annually. In a typical year, about 2,400 km of the bank line experiences major erosion. The unpredictable shifting behaviour of the rivers and their encroachments not only affect the rural floodplain population but also urban growth centre and infrastructures.

No systemic pattern has yet been observed of the erosion hazards because of the involvement of a large number of variables in the process. The intensity of bank erosion varies widely from river to river as it depends on such characteristics as bank material, water level variations, near bank flow velocities, plan form of the river and the supply of water and sediment into the river. For example, loosely packed, recently deposited bank materials, consisting of SILT and fine SAND, are highly 
susceptible to erosion. Rapid recession of floods accelerates the rates of bank erosion in such materials.

The Jamuna is a braided river with bank materials that are highly susceptible to erosion. Since the Brahmaputra switched to the course of the Jamuna at the western side of the Madhupur tract, the average width of the river has fluctuated substantially. The recorded minimum average width of the Jamuna was $5.6 \mathrm{~km}$ in 1914. Locally, the maximum width has often exceeded $15 \mathrm{~km}$, while the recorded local minimum width was about $1.1 \mathrm{~km}$. The rate of widening of the river within the period 1973 to 2000 is $128 \mathrm{~m} /$ year ( $68 \mathrm{~m}$ for the left bank and 60m for the right bank). The annual rate of widening has been as high as $184 \mathrm{~m}$ during 1984-92, of which $100 \mathrm{~m}$ occurred along the left and $84 \mathrm{~m}$ along the right bank (Table 1). In this period, the average width of the river increased from 9.7 to 11.2 $\mathrm{km}$ (Table 2). The maximum bank erosion during 1984-92 occurred at the left bank, just upstream of Aricha. Both rotation and extension bank erosion mechanisms do occur.

The Jamuna has persistently widened from 1973 to the early nineties, but the yearly rate seems to have gone down significantly in the late nineties. The widening of the river in a 28-year period resulted in a loss of floodplain of 70,000 ha over the total $220 \mathrm{~km}$ length of the river in Bangladesh (average about 2,600 ha/year). Within the 1984-92 period, the river has eroded 40,150 ha of floodplain and accreted 7,140 ha, corresponding to an erosion rate of about 5,000 ha/year, and an accretion rate of about 900 ha/year.

Table 1: Riverbank erosion along the different rivers for the period 1984-93.

\begin{tabular}{|l|l|l|l|l|l|l|}
\hline \multicolumn{2}{|l|}{} & Jamuna & Ganges & Padma & $\begin{array}{l}\text { Upper } \\
\text { Meghna }\end{array}$ & $\begin{array}{l}\text { Lower } \\
\text { Meghna }\end{array}$ \\
\hline $\begin{array}{l}\text { Bank } \\
\text { erosion } \\
\text { rate } \\
\mathbf{( m / y r )}\end{array}$ & Left & $* 100$ & -20 & 38 & 7 & 66 \\
\cline { 2 - 7 } & Right & $* 84$ & 56 & 121 & -9 & 182 \\
\hline $\begin{array}{l}\text { Maximum bank erosion } \\
\text { rate (m/yr) }\end{array}$ & $* 784$ & 665 & 620 & NA & 824 \\
\hline Bank erosion (ha/yr) & $* 5,020$ & 2,240 & 1,800 & 48 & 1,172 \\
\hline Bank accretion (ha/yr) & $* 890$ & 1,010 & 233 & 49 & 402 \\
\hline Source: ISPAN, 1995 Note: * Rates derived for the period 1984-92 & \\
\hline
\end{tabular}

Table 2: Change of width of the rivers.

\begin{tabular}{|l|l|l|l|l|l|l|}
\hline \multicolumn{2}{|c|}{} & Jamuna & Ganges & Padma & $\begin{array}{l}\text { Upper } \\
\text { Meghna }\end{array}$ & $\begin{array}{l}\text { Lower } \\
\text { Meghna }\end{array}$ \\
\hline $\begin{array}{l}\text { Average width } \\
\text { (m) }\end{array}$ & $\mathbf{1 9 8 4}$ & 9,720 & 4,367 & 5,689 & 3,406 & 6,661 \\
\cline { 2 - 7 } & $\mathbf{1 9 9 3}$ & $* 11,220$ & 4,693 & 7,116 & 3,391 & 8,897 \\
\hline $\begin{array}{l}\text { Rate of change of } \\
\text { width (m/yr) }\end{array}$ & 184 & 36 & 159 & 2 & 248 \\
\hline \multicolumn{2}{|l|}{ Source: ISPAN, 1995 Note: * Width in 1992 } & & & \\
\hline
\end{tabular}

In recent years, human interventions in the Jamuna are growing construction of the Jamuna Bridge, and bank protection structures at Sirajganj, Sariakandi and Bahadurabad will doubtless have some influence on the changes of the width of the river. These types of structures are reducing the freedom of the river to widen through bank erosion.

The Ganges the bank material within the active corridor of the Ganges consists of loosely packed sand and silt. These materials are highly susceptible to erosion. The bank erosion process along the Ganges is controlled mainly by its wandering planform characteristics. In the braiding reaches, the river can erode along both banks, as can be seen in the reaches downstream of the Hardinge Bridge. Maximum 
bank erosion, however, occurs in the meandering reaches, where the outer bend can still migrate laterally within the corridor. In the period 1984-93, the maximum observed rate was $665 \mathrm{~m} /$ year. Along the right and left bank of the Ganges, erosion rates are $56 \mathrm{~m}$ and $20 \mathrm{~m}$ per year respectively, which is lower than the rates observed in the Jamuna. The width of the river varied from 1.7 to $10 \mathrm{~km}$ in 1984 and from 1.9 to $11.7 \mathrm{~km}$ in 1993 . The average width of the river in 1984 was $4.37 \mathrm{~km}$, which increased to $4.69 \mathrm{~km}$ in 1993 . The widening rate of the river is $36 \mathrm{~m} /$ year, which is about one-fifth of the Jamuna. The widening of the Ganges is not considered significant.

\section{Scio-economic Impact:}

Socio-economic impact riverbank erosion has disastrous socio-economic effects. The majority of the affected people perceive riverbank erosion as a natural phenomenon but in many cases the people believe erosion to be the 'will of God'. However, these days, riverbank erosion is seen as one of the major causes for national poverty. The degree of economic loss and vulnerability of population due to bank erosion has dramatically increased in recent years. The impact of land loss involves primarily the loss of homestead land, housing structures, crops, cattle, trees and household utensils. Loss of homesteads forces people to move to new places without any option and puts them in disastrous situations. About one million people are directly affected each year by bank erosion in the country. The total monetary loss is estimated to be approximately US\$500 million a year. An estimated 300,000 displaced persons usually take shelter on roads, embankments and government-requisitioned lands. Bank erosion affects people, irrespective of farm sizes. Riverbank erosion causes setback for village agriculture. Along with homestead settlements, it erodes farmland, infrastructure and the communication system. It affects the crop income of vulnerable groups. The big farmers are the worst affected, followed by medium farmers, and marginal groups. The affected people lose their assets and are forced to draw on savings and often fall into further debt. Researchers found that the land lost is much more than the land that rises out of riverbed through accretion. This erosion-accretion phenomenon is a characteristic feature of the courses of the rivers in Bangladesh and gives rise to a lot of tension in local politics.

Displacement is the immediate impact of riverbank erosion. The displaced usually move to nearby areas but migrations to distant places are not uncommon. In erosion-prone areas, most families have witnessed a displacement in their lifetime. This involuntary movement can go up to 10 times or even more. A survey conducted in two Dhaka slums has revealed that they consist of migrants who mostly originated from the districts of Faridpur (34\%), Barisal (25.6\%), Comilla (24.3\%) and Dhaka (14.3\%). A closer examination of this distribution further revealed that most of the migrants came from an area consisting of only a few upazilas mostly located around the Ganges-Padma and the Meghna and their combined estuaries. The displacement caused by erosion, mostly involve displacement of whole families. On an average, a household experienced riverbank erosion 2.33 times in the life of its members. Some of them experienced displacement 4-5 times or more. Most of the environmentinduced refugees turn mainly into labourers or rickshaw pullers. A large proportion of the victims remain unemployed due to lack of work opportunities. Moreover, women head many of these families. The female-headed households displaced by riverbank erosion and residing on embankments are the most deprived group. Fortunately, nowadays, social workers are focusing on these problems and also suggesting strategies of survival to these people.

The Brahmaputra-Jamuna is the second largest river in Bangladesh and one of the largest in the world, with its basin covering areas in Tibet, China, India and Bangladesh. Actually Jamuna is the downstream course of the Brahmaputra which took place after the earthquake and catastrophic flood in 1787. Presently the Brahmaputra continues southeast from Bahadurabad (Dewanganj upazila of 
Jamalpur district) as the Old Brahmaputra and the river between Bahadurabad and Aricha is the Jamuna, not Brahmaputra. The Hydrology Directorate of the Bangladesh Water Development Board (BWBD) refers to the whole stretch as the Brahmaputra-Jamuna.

The catchment of the mighty Brahmaputra-Jamuna river is about 5,83,000sq km of which 293,000sq $\mathrm{km}$ are in Tibet, 241,000sq km in India and only 47,000 sq km within Bangladesh. The drainage area above Bahadurabad is 536,000sq km. This is the widest river system in the country flowing northsouth. The discharge during the rainy season is enormous, averaging 40,000cumec, by which measure it ranks with the Amazon, Congo, La Plata, Yangtse, Mississippi and Meghna as one of the seven largest rivers. The highest recorded flood was 98,600cumec in August 1988.

Average annual flow at Bahadurabad is estimated to be 501 million acre-feet. August has always been the month when widespread flooding has been most likely. Floods from May to July are usually due to the Brahmaputra-Jamuna and Meghna. From August to October due to the combined flows of those rivers and the Ganges. As a rule, the flow of the Brahmaputra-Jamuna is more erratic than that of the Ganges. The gradient of the Jamuna averages 1:11,850 which is slightly more than that of the Ganges. The Jamuna discharges a large volume of water and at the same time brings in huge amounts of sediments. During the rainy season it brings down something like 1.2 million tons of sediment daily, and the annual silt runoff at Bahadurabad is estimated at 735 million tons.

Recently a $4.8 \mathrm{~km}$ long bridge has been constructed over the Jamuna for linking the eastern and western parts of Bangladesh. The eastern edge of Jamuna Bridge lies in Bhuapur upazila of Tangail district and the western end in Sirajganj Sadar upazila of Sirajganj district. Apart from quick movement of goods and passenger traffic by road and rail, it has facilitated transmission of electricity and natural gas, and integration of telecommunication links. The bridge was opened for traffic on 23 June 1998. A considerable volume of river training work was done to keep the river within the bridge instead of a flood-width of $14 \mathrm{~km}$ at the bridge site.

The Jamuna is braided in nature. Within the braided belt of the Jamuna, there are lots of chars of different sizes. An assessment of the 1992 dry season Landsat image shows that the Jamuna contained a total of 56 large island chars, each longer than $3.5 \mathrm{~km}$. There were an additional number of 226 small island chars, varying in length between 0.35 and $3.5 \mathrm{~km}$. This includes sandy areas as well as vegetated chars. In the Jamuna the period between 1973 and 2000, chars have consistently appeared in the reaches opposite to the Old Brahmaputra offtakes, north and east of Sirajganj and in the southernmost reach above the confluence with the Ganges. In entire Bangladesh during 1981 to 1993, a total of about 729,000 people were displaced by riverbank erosion. More than half of the displacement was along the Jamuna.

\section{CONCLUSION}

This study has been conducted to focus on the socio-economic and environmental conditions of the riverbank erosion victims of Bangladesh. Without any adequate institutional and structural support the victims own formulated and undertaken strategies to confront the precarious condition. They make efforts both physically and socially to survive with the precarious conditions by riverbank erosion. It is found that the influences of the ecological and the socio-economic conditions and the formulated and undertaken strategies by the victims are effective to survive with the changing environment. The existing conditions influence them to formulate this kind of strategies.

By developing social relationships with their social counterparts the victims of riverbank erosion have adopted more effective strategy in coping with their precarious conditions. They share sorrows and pleasures with their counterparts. This study explores the existing socio-economic and environmental 
conditions of riverbank erosion victims. This study also explores the survival strategies in precarious condition by the victims. This study has both academic and policy related implications. In this decade of environment, the policymakers and development researchers at the national need to be aware of the nature of socio-economic and environmental conditions of riverbank erosion victims in Bangladesh. Every year caused riverbank erosion unemployment landlessness and poverty is increasing which is responsible for the unstable condition in whole the country.

\section{ACKNOWLEDGEMENT}

I express my sincere gratitude to the concerned authority of web pages (www.cosis.net, www.ingentaconnect.com, www.jrbm.net, www.metropolis2007.com, www.reliefweb.int.org www.millennumassessment.org) for their valuable contents. I also express my thanks to the concerned authority of referred article authority.

\section{REFERENCES}

Ahmad QK. (ed) 2000. Bangladesh Water Vision:Towards a Sustainable Water World. Bangladesh Water Partnership. Dhaka, Bangladesh.

Alam J. 1986. Erosion at 283 place, Holiday, XXII, 5p.

Ali A. 2000. Vulnerability of Bangladesh to Climate Change and Sea Level Rise, Paper Presented in the International Day for Disaster Reduction Seminar, 11 October 2000, Dhaka, Bangladesh. BBS 1979. Statistical Yearbook of Bangladesh. Dacca.

BBS 1984. Bangladesh Cencus of Agriculture and Livestock. Dhaka.

Chowdhury MHK. and Hussain A. 1981. Aridity and Drought Conditions of Bangladesh. Tropical Droughts (Meteorological Aspects and Implications for Agriculture). Journal of WMO Program on Research in Tropical Meteorology, pp 73-80. New Delhi, India.

Elahi KM, John RR and Rogge JR.1990. Riverbank erosion, flood and population displacement in Bangladesh: A report on the riverbank erosion impact study, Dhaka: Riverbank Erosion Impact Study (REIS), Jahangirnagar University (JU).

Elahi KM. 1991. Riverbank Erosion, Flood Hazard and Population Displacement in Bangladesh: An Overview. In Elahi, K. M., Ahmed, K. S., and Mafizuddin, M. (eds), Riverbank Erosion, Flood Hazard and Population Displacement in Bangladesh. Dhaka, Riverbank Erosion Impact Study (REIS), 364 pp [From Khalequzzaman].

Faruque A. 2007. Resettlement Policy Resettlement Policy Development: The Case of Development: The Case of Bangladesh. Asian Development Bank Asian Development Bank . Bangladesh Bangladesh, Resident Mission, PowerPoint Presentation.

Haque CE. 1988. Impacts of Riverbank erosion Hazard in Brahmaputra Jamuna Floodplain: A study of population displacement and response strategies. PhD Thesis, Department of Geography, University of Mintoba, Canada.

Haque CE. and Zaman MQ. 1993. Human Response to Riverive Hazards in Bangladesh: A Proposal for Sustainable Floodplain Development. World Development, v. 21(1), p. 217-29.

http://www.cosis.net/abstracts/COSPAR2006/00738/COSPAR2006-A-00738.pdf

http://www.ingentaconnect.com/content/bpl/disa/2004/00000028/00000001/art000

03;jsessionid=2hcpbncdhmb3r.alice?format=print

http://www.jrbm.net/pages/archives/JRBMn1/Sarker.PDF 
http://www.metropolis2007.org/WorkshopTuesday/Ahmned_Faruque_Tues_Mercure_Fig.pdf 35

http://www.millenniumassessment.org/documents/document.316.aspx.pdf

http://www.reliefweb.int/rw/rwb.nsf/AllDocsByUNID/4a40ee0d52510b16c125694b00

Huq, S. (ed.) 1999. Vulnerability and Adaptation to Climate Change for Bangladesh. Kluwer Academic Publishers, Netherlands.

Islam MS. and Islam AMZ. 1985. A brief account on Bank erosion, Model, Studies and Bank Protective Works in Bangladesh, REIS Newsletter 2: 10-13.

Milliman JD. Broadus JM. and Frank G. 1989. Environmental and Economic Impact of Rising Sea Level and Subsiding Deltas: The Nile and Bengal Examples. In Bangladesh Quest. 1:11-12.

Pramanik MAH. 1991. Natural Disasters. Article prepared for Bangladesh Space Research and Remote Sensing Organization (SPARRSO). Dhaka, Bangladesh.

Rahman A. 1986. Impact of Riverbank Erosion: Survival Strategies of Displacees, ADAB News, XVII.

Rashid H. 1991. Geography of Bangladesh. The University Press Limited. Dhaka, Bangladesh.

Rashid H. and Pramanik MAH. 1990. Visual Interpretation of Satellite Imagery for Monitoring Floods in Bangladesh. Springer-Verlag New York Inc. U.S.A.

Rogge JR. 1991. Individual and institutional response to riverbank erosion hazards. In: KM Elahi KS. KS Ahmed and M Mafizuddin (eds.), Riverbank Erosion, Flood and Population Displacement in Bangladesh. Dhaka: REIS, JU.

Viswanathan S. and Ravi S. 2007. Learning from the Poor: Findings from Participatory Poverty Assessments in India. Manila: Asian Development Bank. http://www.adb.org/Documents/Books/Learning-From-the-Poor/Learning-From-the-Poor.pdf

Zaman MQ. 1986. Rural Bastees-economicand political dynamics of Accretiona and depositional and development land erosion and flood hazard hazards in Bangladesh, Dhaka: Jahangirnagar University, 16p. 